UDC 614.38

DOI: 10.21668/health.risk/2018.1.12.eng

\title{
INTERDEPARTMENTAL INTERACTION ON PROVIDING BIOLOGICAL SAFE- TYON TATARSTAN REPUBLIC TERRITORY DURING PREPARATIONS FOR 2017 FIFA CONFEDERATIONS CUP IN KAZAN
}

\author{
M.A. Patyashina, M.V. Trofimova, L.G. Avdonina, L.T. Garaeva, G.R. Mansurova \\ Federal Service for Surveillance over Consumer Rights Protection and Human Well-being, Tatarstan Regional \\ Office, 30 B. Krasnaya Str., Kazan', 420111, Russian Federation
}

Infectious agents collections used in practical work are to be securely protected as they can cause infections among people and animals; they are potential biological terrorism objects including periods when mass sport, political, or cultural events take place in the country. It made our research truly vital. Our research goal was to analyze an interdepartmental workgroup functioning aimed at inspecting objects located on areas where 2017 FIFA Confederations Cup and 2018 FIFA World Championship were to take place. This workgroup had to deal with biological substances, biological and microbiological organisms and infectious agents from II-IV pathogenicity groups. Its basic task was to minimize biological hazards during work with pathogenic biological agents. The research involved examination of legal documents (including international ones) which regulated biological safety requirements for work with pathogenic biological agents; consideration of joint work with the RF Federal Security Service, Tatarstan Regional Office, Tatarstan Anti-Terrorism Commission for providing anti-terroristic protection of organizations dealing with infectious agents, including those common for people and animals, on the example of Rospotrebnadzor Regional Office in Tatarstan; analysis of work performed by the interdepartmental workgroup.

It is shown that efficient interdepartmental interaction allowed to provide biological safety in Kazan and on adjoining territories, to prevent pathogen entering the environment and possibility to use pathogenic biological agents as biological terrorism objects during preparation for 2017 FIFA Confederation Cup and the event itself.

Key words: anti-terroristic security, infectious diseases, biological safety, biological hazard, biological terrorism, biologically hazardous object.

Rospotrebnadzor Regional Office in functioning allowed to provide biological Tatarstan (hereinafter called "The Office") safety during preparations to 2017 FIFA is to control biological safety provision in Confederation Cup in Kazan and during the the Republic of Tatarstan ${ }^{1,2,3}$. Newly de- event. veloped organizational procedures imple- In accordance with the federal legislamented in an interdepartmental workgroup tion on obligatory licensing of specific activ-

(C) Patyashina M.A., Trofimova M.V., Avdonina L.G., Garaeva L.T., Mansurova G.R., 2018

Marina A. Patyashina - Doctor of Medical Sciences; Director (e-mail: org@,16.rospotrebnadzor.ru; tel.: +7 (843) 238-98-54).

Marina V. Trofimova - Deputy Director (e-mail: org@16.rospotrebnadzor.ru; tel.: +7 (843) 238-98-54).

Lyubov' G. Avdonina - Deputy Director (e-mail: org@16.rospotrebnadzor.ru; tel.: +7 (843) 238-98-54).

Liliya T. Garaeva - Head of State Registrationand Licensing Department (e-mail: Garaeva.LT@tatar.ru; tel.: +7 (843) 238-53-28).

Guzel' R. Mansurova - expert-researcherat State Registrationand Licensing Department (e-mail: rpn.licenz@tatar.ru; tel.: +7 (843) 238-53-28). 
ities $^{4}$ all the activities performed in closed systems in the sphere where agents of human and animals infectious diseases (excluding those activities which are performed in the medical sphere) and genetically modified organisms with III and IV potential hazard categories are applied are to be licensed. Such activities can cause a situation when there is a violation of citizens' rights, legitimate interests, lives or health, or there can be a damage to the environment, the defense and safety of the state. Starting from 1996 Rospotrebnadzor bears the full responsibility for the state regulation of licensing activities in the sphere where agents of human and animals infectious diseases are applied.

The state system for providing biological safety is an essential component in the RF national security system. It is a set of organizational and technical procedures aimed at preventing damage and providing protection of an individual, the society in general, and the state itself from potential and actual biological hazards. The latter can appear as a natural or deliberate lesion with such biological agents as bacteria, viruses, fungi, protozoa, or their toxins ${ }^{5}$.

Collections of human and animals infectious diseases agents are regularly applied in practical work. Such collections are potential objects for biological terrorism and their protection is an essential part of the state policy aimed at providing sanitary-epidemiologic safety [1].

Anna Yu. Popova, the RF Chief Sanitary Inspector and the Head of Rospotrebnadzor, has repeatedly stressed the importance of the issue; she has reminded that there are events which usually cause biological risks. Such events are natural disasters during which biological pathogens transfer paths become extremely active; emergencies at potentially hazardous biological objects; biological terrorism acts; uncontrolled spread of genetically modified microorganisms; mass production and sales of genetically modified food products and agricultural products; development of biological weapons belonging to a new generation [2].

Moreover, there are situations when a pathogenic biological agent has been deliberately applied. The latest event of the kind was registered in the USA in 2015 when alive anthrax cultures were sent from a biological laboratory of the US Defense Ministry to dozens various organizations, including those located in 9 foreign countries in Europe and Asia [3].

International scientific society has developed a unified approach to providing

${ }^{1}$ On licensing activities performed in closed systems in the sphere where agents of human and animals infectious diseases (excluding those activities which are performed in the medical sphere) and genetically modified organisms with III and IV potential hazard categories are applied: The RF Government Regulation dated April 16, 2012 No. 317 (edited on March 06, 2015). Available at: http://www.consultant.ru/document/cons doc LAW_128582/ (26.12.2017).

${ }^{2}$ SR 1.3.2322-08. Safety of work with microorganisms from III - IV pathogenicity (hazards) groups and parasitic diseases agents: Sanitary Rules. 2008. Available at: http://docs.cntd.ru/document/902091086 (22.12.2017).

${ }^{3}$ On approval of sanitary-epidemiologic rules SR 1.3.3118-13 "Safety of work with microorganisms from I-II pathogenicity (hazards) groups": The Order by the RF Chief Sanitary Inspector. 2013. Available at: http://docs.cntd.ru/document/499061798 (22.12.2017).

${ }^{4}$ On obligatory licensing of specific activities: The RF Federal Law issued on May 04, 2011 No. 99-FL (the latest edition came into force on January 1, 2018). Available at: http://docs.cntd.ru/document/902276657 (10.01.2018).

${ }^{5}$ The basics of the state policy in the sphere of providing chemical and biological safety in the Russian Federation for the period up to 2025 and further on / approved by the RF President on November 01, 2013 No. Pr-2573. 2013. Available at: http://www.garant.ru/products/ipo/prime/doc/70423098/ (26.12.2017). 
public and individual safety during work with pathogens $[4,5]$, and a guidance on biological protection of laboratories $[6,7]$; there are standards for managing laboratory biological risks [1, 8-10].

In December 2017 the member states of the Biological and Toxin Weapons Convention held a meeting in Geneva; they adopted a work program for 2018-2020 aimed at reducing risks for biological safety caused by a threat when bacteriological (biological) agents or toxins could be used as a weapon. The program includes the following basic subject: monitoring over scientific research in the biological sphere which could potentially have double application [11].

In 2008 new sanitary rules fixed the requirements to work with microorganisms from III - IV pathogenicity groups2; in 2013 the same was done for microorganisms from I - II pathogenicity groups 3 , and it made all the requirements to providing individual and public safety and environmental protection during work with pathogenic biological agents more strict.

Research goals and tasks. To analyze work done by the interdepartmental workgroup which was created to provide safe work with pathogenic biological agents (PBA). This team examined objects located on territories where 2017 FIFA Confederation Cup and 2018 FIFA World Championship were to take place. The objects under surveillance were those working with biological substances, biological and microbiological organisms, and infectious diseases agents from II-IV pathogenicity groups.

Data and methods. We examined legal documents, including international ones, which set forth the requirements to biological safety during work with PBA; considered how cooperation with RF Federal Se- curity Service, Tatarstan Regional Office and Tatarstan Anti-Terrorism Commission was organized, its goals being to provide anti-terroristic safety of organizations dealing with infectious agents, including those common for people and animals on the example of Rospotrebnadzor Regional Office in Tatarstan; analyzed work performed by the interdepartmental workgroup.

Results and discussion. Safety precautions aimed at enhancing anti-terrorist protection and providing biological safety were adopted by The Office during preparation to 2017 FIFA Confederation Cup and the event itself.

In order to prevent biological terrorism, to enhance anti-terrorist protection, and to provide biological safety during 2018 FIFA World Championship, on December 24, 2015 the Head of the RF Federal Security Service, Tatarstan Regional Office majorgeneral D.G. Khamitov [12] approved on the Register of industrial and infrastructural objects (hereinafter called "The Register") (critically essential, potentially hazardous and hazardous ones) located on territories where 2017 FIFA Confederation Cup and 2018 FIFA World Championship were to take place. Should such objects be put out of action (as a result of a subversive-terroristic act, or an emergency), it would threaten safety during these events (Figure1).

The Register was updated on the initiative of The Office by the EMERCOM of Russia, Tatarstan Regional Office (the RF Ministry on civil defense, emergencies, and elimination of natural disasters consequences). The Register included 40 laboratories (16 medical organizations, 9 communal objects, 7 food industry enterprises, 3 veterinary clinics, 3 industrial enterprises, and 2 scientific and educational institutions). 
The Head of the Regional workgroup on providing safety during FIFA 2018 World Championship and the Head of the RF Federal Security Service, Tatarstan Regional Office approved the Register of industrial and infrastructural objects (criticall essential, potentially hazardous, and hazardous ones)

December 24, 2015; December 26, 2016

The Register was updated on the initiative of Rospotrebnadzor Regional Office in tatarstan and the EMERCOM of Russian f Tatarstan Regional Office in December 2016

Figure.1. Interaction between controlling authorities

The Office drew up a map of Kazan city with adjoining territories; the map showed location of economic entities which dealt with biological substances, biological and microbiological organisms, and with infectious diseases agents from II - IV pathogenicity groups; it also showed sport objects where events of FIFA 2018 World Championship were to take place.

In November-December 2016 all the economic entities updated their documents which confirmed safety of a biologically hazardous object; their duplicates were sent to The Office [13].

In 2016 The Office sent 5 information letters to the Tatarstan Public healthcare Ministry stating that 4 medical organizations had problems in providing biological safety in their laboratories.

In the first half year 2017 the Tatarstan Public Healthcare Ministry, the Chief Veterinary Office at the Tatarstan Cabinet, and the Office held several meeting with heads and laboratory specialists from those economic entities which dealt with biological substances and infectious diseases agents; the meetings were organized to discuss issues related to providing biological safety and anti-terrorist protection of biologically hazardous objects.

The Tatarstan Minister for civil defense and emergencies (the Head of the EMERCOM of Russia, Regional Tatarstan Office) was sent some propositions to be included into a draft regulation by the Tatarstan Cabinet "on organizing radiation, chemical, and biological protection and control during preparations to FIFA 2017 Confederation Cup and the event itself in Kazan" [12].

In 201740 letters were sent to economic entities stating that they should implement additional measures on anti-terrorist protection. All the juridical persons had to confirm that they followed all the requirements to biological safety when dealing with pathogens providing this information to The Office (Figure 2).

The Office experts were members of the interdepartmental workgroup organized to examine objects located on territories where the FIFA 2017 Confederation Cup 
and the FIFA 2018 world Championship 2017 and controlled biological safety pro(IWG for short). They inspected 29 juridi- vision during work with pathogenic biologcal persons from October 2016 to May ical agents2,3 [14, 15] (Figure 3).

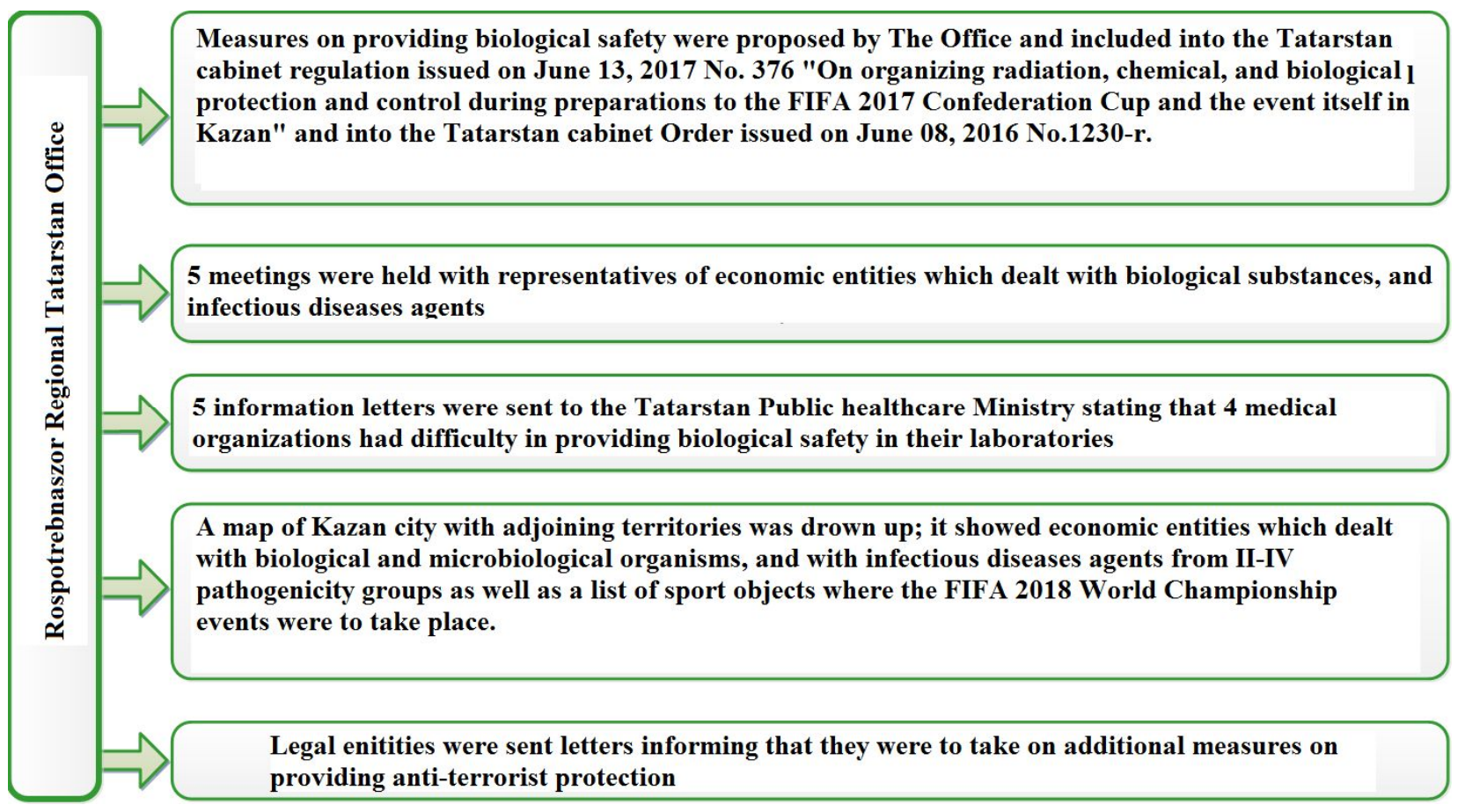

Figure 2. Activities performed by The Office during preparations to the FIFA 2017 Confederation Cup and the event itself.

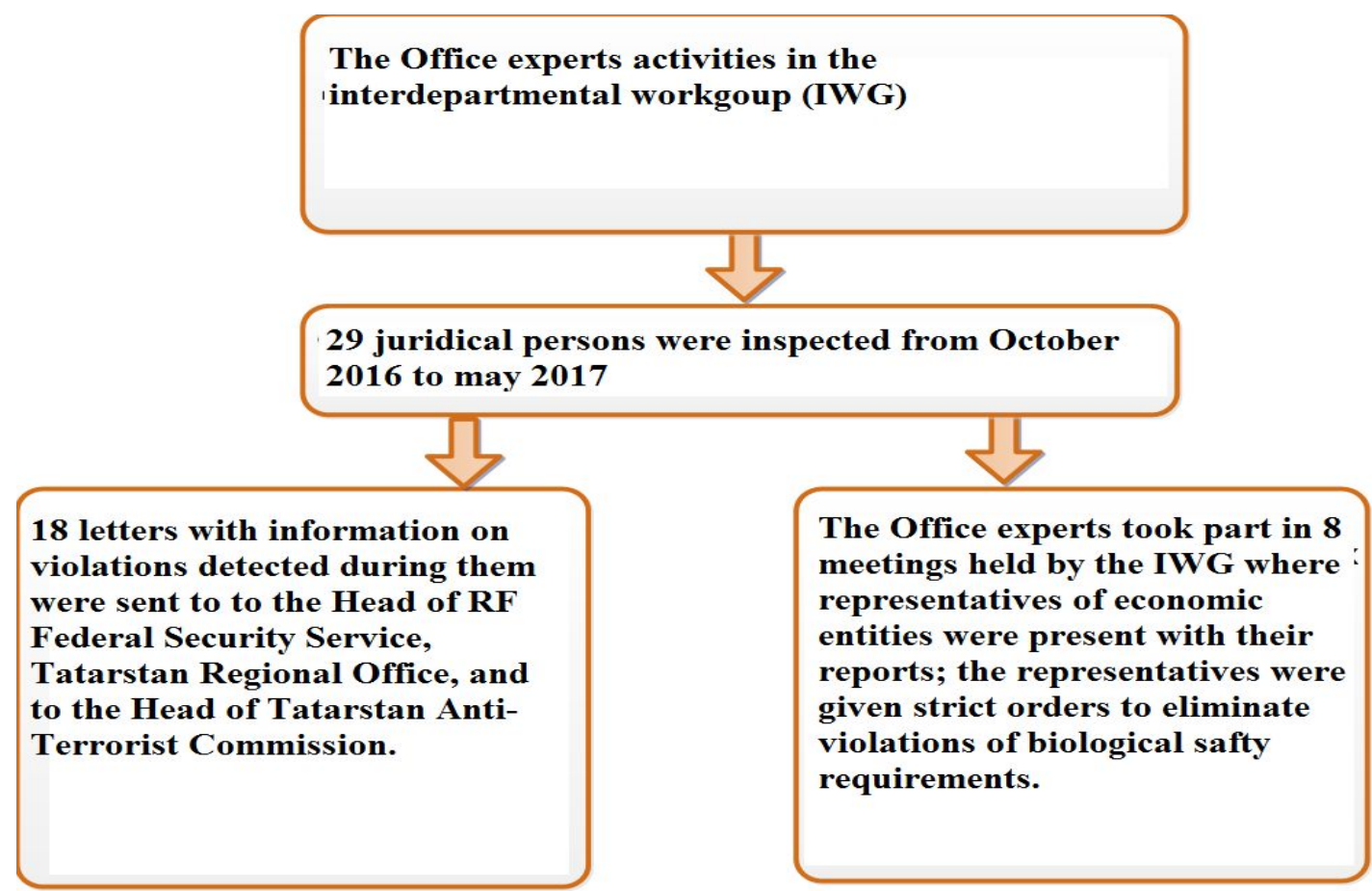

Figure 3. The Office experts activities in the interdepartmental workgroup. 
As per inspections results 18 letters with information on violations detected during them were sent to the Head of the interdepartmental operating authority responsible for providing safety during the FIFA 2017 Confederation Cup and the FIFA 2018 World Championship events, to the Head of RF Federal Security Service, Tatarstan Regional Office, and to the Head of Tatarstan Anti-Terrorist Commission.

The RF Federals Security Service, Tatarstan Regional office, held 8 meetings where representatives of economic entities made their reports; the representatives were given strict orders to eliminate violations of biological safety requirements.

The IWG made a decision on its final meeting to stop work with biological sub- stances, biological and microbiological organisms, and with infectious diseases agents in laboratories at 5 economic entities.

In order to provide execution of the RF Governmental Order issued on June 09, 2017 No. 689 "On certain measures aimed at implementing The RF President Order signed on may 09, 2017 No. 202 "On peculiarities of taking on enhanced safety precautions during the FIFA 2017 Confederation Cup and the FIFA 2018 World Championship in the Russian Federation" [16], the following measures were implemented concerning 40 juridical persons included in the Register (Figure 4):

\section{The results of The Office activities aimed at execution of the RF Governmental Order issued on June 09, 2017 No. 689 "On certain measures aimed at implementing The RF President Order signed on may 09, 2017 No. 202 "On peculiarities of taking on enhanced safety precautions during the FIFA 2017 Confederation Cup and the FIFA 2018 World Championship in the Russian Federation"}

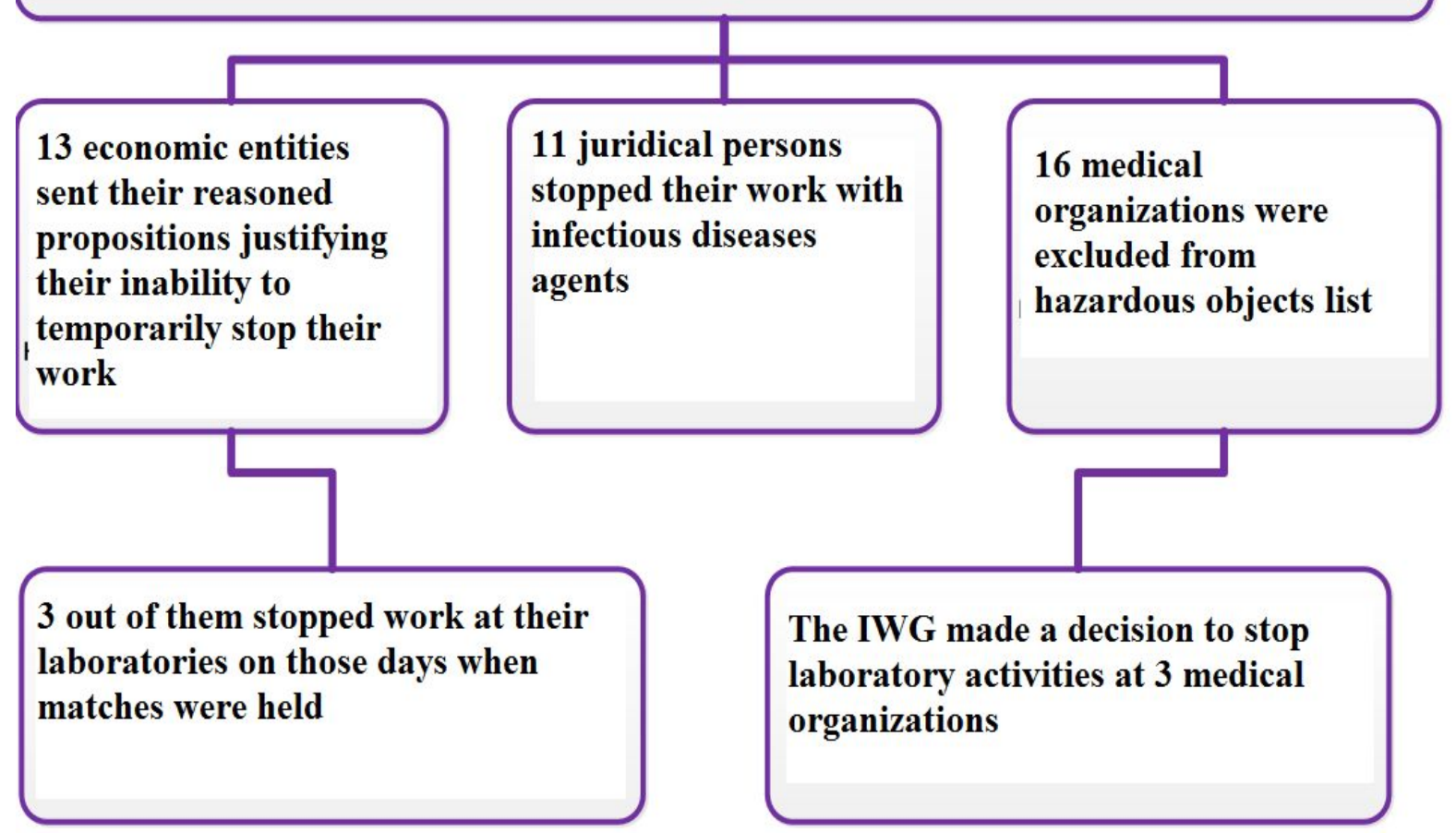

Figure 4. Execution of the RF Governmental Order issued on June 09, 2017 No. 689. 
-13 economic entities sent their reasoned proposition to The Office and The Tatarstan Industry and Trade Ministry justifying their inability to temporarily stop their work with biological substances as such work was closely connected with surveillance and laboratory control over the environment, food products and water supply safety, and infectious diseases diagnostics among participants and visitors of the FIFA 2017 Confederation Cup. But at the same time 3 out of them made a break in their work on those days when matches were held;

-11 juridical persons stopped their work with infectious diseases agents for the whole period of the FIFA 2017 Confederation Cup;
-16 medical organizations were excluded from the list of hazardous objects approved by the RF Governmental Order dated June 09, 2017, No. 689. However, as the IWG detected violations of biological safety requirements, laboratory activities at 3 medical organizations were prohibited by its decision for the period when the FIFA 2017 Confederation Cup took place, name1y, from June 12, 2017 to July 12, 2017.

Conclusions. Efficient interdepartmental interaction aimed at providing biological safety during preparation to the FIFA 2017 Confederation Cup and the event itself allowed to prevent pathogens entering the environment or possible PBA application as biological terrorism objects.

\section{References}

1. Barras V., Greub G. History of biological war fare and bioterrorism. Clin. Microbiol. Infect., 2014, vol. 20, no. 6, pp. 497-502. DOI: 10.1111/1469-0691.12706

2. Krasnopol'skaya I. "Igry" s genomom: Glava Rospotrebnadzora Anna Popova ob ugroze biologicheskoi bezopasnosti i kak ei protivostoyat' ["Playing" with genome: Anna Popova, Head of Rospotrabnadzor, on threats to biological safety and how to fight]. Rossiiskaya gazeta - Federal'nyi vypusk, 2017, no. 7433 (267). Available at: https://rg.ru/2017/11/23/glava-rospotrebnadzorarasskazala-ob-ugroze-biologicheskoj-bezopasnosti.html (22.12.2017) (in Russian).

3. O Konventsii o zapreshchenii biologicheskogoi toksinnogo oruzhiya (KBTO): Pis'mo Federal'noi sluzhby po nadzoru v sfere zashchity prav potrebitelei i blagopoluchiya cheloveka ot 17.08.2015 [On Convention on Biological and Toxic Weapons: a Letter by the Federal Service for Surveillance over Consumer Rights Protection and Human Well-being dated August 17, 2015]. Available at: http://www.rospotrebnadzor.ru/about/info/news/news details.php?ELEMENT_ID=4042 (26.12.2017) (in Russian).

4. Cavallari E., de Lellis L., Stefanelli G.P., Lorenzini T. Biological risk in non-clinical biological and chemical laboratories. G. Ital. Med. Lav. Ergon., 2008, vol. 30, no. 1, pp. 22-32.

5. Biorisk management: Laboratory biosecurity guidance. World Health Organization, Ge-

neva, 2006, 41 p. Available at: https://www.google.ru/url?sa=t\&rct=j\&q=\&esrc=s\&source=web\&cd=1\&ved=0ahUKEwjhnNO jnY7a

AhXExKYKHf4iCDcQFggoMAA\&url=http\%3A\%2F\%2Fwww.who.int $\% 2 \mathrm{Fcsr} \% 2$ Fresources \%2Fpublications\%2Fbiosafety\%2FWHO_CDS_EPR_2006_6.pdf\&usg=AOvVaw3-e7dS4w5j295IzWhKru2 (26.12.2017).

6. Biosafety in microbiological and biomedical laboratories. 5th ed. U.S. Depart-ment of Health and Human Services; Public Health Service, 2009, 438 p. Available at: https://www.cdc.gov/biosafety/publications/bmbl5/bmbl.pdf (25.12.2017). 
7. Burns G., Pharmaceuticals A.Z., See-churn P. CWA 15793: 2008. Laboratory biorisk management standard / Northern BSOs Meeting, Glasgow, 2009, 25 p.

8. Laboratory biosafety manual. 3rd ed. World Health Organization, Geneva, 2004, 186 p. Available at: www.who.int/csr/resources/publications/biosafety/Biosafety7.pdf (28.12.2017).

9. Laboratory biosafety guidelines. 3rd ed. Canada, 2004, 125 p. Available at: https://www.canada.ca/en/public-health/services/canadian-biosafety-standards-guidelines/laboratory-biosafetyguidelines-3rd-edition-2004.html (22.12.2017).

10. Laboratory Biorisk Management: Strategic Framework for Action 2012-2016. World Health Organization, Geneva, 2012, 16 p. Available at: http://www.who.int/ihr/publications/strategic framework/en/ (10.01.2018).

11. O Konvektsii o zapreshchenii biologicheskogo i toksinnogo oruzhiya: Pis'mo Federal'noi sluzhby po nadzoru $\mathrm{v}$ sfere zashchity prav potrebitelei i blagopoluchiya cheloveka ot 22.12.2017 [On Convention on Biological and Toxic Weapons: a Letter by the Federal Service for Surveillance over Consumer Rights Protection and Human Well-being dated December 22, 2017]. Available at: http://rospotrebnadzor.ru/about/info/news/news_details.php? ELEMENT_ID=9377 (26.12.2017) (in Russian).

12. MR 0100/3556-04-34. Vzaimodeistvie organov upravleniya, uchrezhdenii I spetsializirovannykh formirovanii pri likvidatsii posledstvii terroristicheskikh aktov s primeneniem patogennykh biologicheskikh agentov i opasnykh khimicheskikh veshchestv: metodicheskie rekomendatsii [Interaction between public authorities, institutions, and specialized formations when eliminating consequences of terroristic attacks with pathogenic biological agents and hazardous chemicals application: Methodical Guidelines]. Available at: https://stategovernor.admhmao.ru/upload/iblock/29d/mr_rospotrebnadzora_po_khimii_2004_god_pdf

(26.12.2017) (in Russian).

13. Ob utverzhdenii tipovogo pasporta bezopasnosti opasnogo ob"ekta: prikaz MChS RF № 506 ot 04.11.2004 [On Approval of a Typical Safety Passport for a hazardous object: The Order issued by EMERCOM of Russia on November 04, 2004 No. 506]. Available at: http://www.mchs.gov.ru/document/4320005 (26.12.2017) (in Russian).

14. MUK 3.1.2964-11. Postroenie sistemy fizicheskoi zashchity gosudarstvennykh i issledovatel'skikh kollektsii mikroorganizmov I-II grupppatogennosti: metodicheskie ukazaniya [Building up a physical protection system for state and research collections of microorganisms from I-II pathogenicity groups: Methodical Guidelines]. Moscow, Federal'nyi tsentr gigieny i epidemiologii Rospotrebnadzora Publ., 2011, 20 p. (in Russian).

15. MU 3.1.3294-15. Postroenie sistemy fizicheskoi zashchity organizatsii, rabotayushchikh s mikroorganizmami I-II grupp patogennosti: metodicheskie ukazaniya [Building up a physical protection system for organizations dealing with microorganisms from I-II pathogenicity groups: Methodical Guidelines]. Moscow, Federal'nyi tsentr gigieny i epidemiologii Rospotrebnadzora Publ., 2016. Available at: http://docs.cntd.ru/document/456023987 (26.12.2017) (in Russian).

16. O nekotorykh merakh porealizatsii Ukaza Prezidenta Rossiiskoi Federatsii ot № 2029 maya 2017 g. «Ob osobennostyakh primeneniya usilennykh merbezopasnosti v period provedeniya v Rossiiskoi Federatsii chempionata mira po futbolu FIFA 2018 goda i Kubka konfederatsii FIFA 2017 goda»: postanovlenie Pravitel'stva Rossiiskoi Federatsii № 689 ot 09.06.2017 [On certain measures aimed at implementing The RF President Order issued on May 9, 2017 No. 202 "On peculiarities of enforced security precautions during2018 FIFA World Championship and 2017 FIFA Confederation Cup in the RF": the RF Government Order issued No. 689 on June 09, 2017]. Available at: https://www.garant.ru/products/ipo/prime/doc/71594832/ (26.12.2017) (in Russian). 
Patyashina M.A., Trofimova M.V., Avdonina L.G., Garaeva L.T., Mansurova G.R. Interdepartmental interaction on providing biological safetyon Tatarstan republic territory during preparations for 2017 FIFA confederations cup in Kazan. Health Risk Analysis, 2018, no. 1, pp. 104-112. DOI: 10.21668/health.risk/2018.1.12.eng

Received: 19.01.2018

Accepted: 20.03.2018

Published: 30.03 .2018 